\title{
Financeirização: conceitos, experiências e a relevância para o campo do planejamento urbano brasileiro
}

\author{
Financialization: concepts, experiences \\ and relevance to the field of Brazilian urban planning
}

Jeroen Klink

Marcos Barcellos de Souza

\section{Resumo}

Este artigo apresenta uma sistematização da literatura internacional e nacional acerca do fenômeno da financeirização e analisa a relevância do debate para o campo de planejamento urbano-metropolitano, priorizando as questões brasileiras. Parte do reconhecimento de que a literatura internacional sobre financeirização avançou significativamente, e alguns autores já apontam para um possível esgotamento do conceito. No entanto, argumenta que há grande potencial de exploração conceitual, metodológica e empírica sobre processos de financeirização em andamento no Brasil, assim como dos seus limites políticos. Discute os vetores da financeirização urbana no Brasil que se dá no entrelaçamento de grandes projetos urbanos, nos mecanismos de financiamento e crédito públicos e na própria transformação da atuação territorial do Estado e de seus instrumentos de planejamento. $\mathrm{Na}$ conclusão, explora elementos para uma agenda de pesquisa sobre financeirização com relevância para o campo de planejamento urbano no Brasil.

Palavras-chave: financeirização; estado; planejamento urbano; escalas espaciais; austeridade.

\begin{abstract}
This paper reviews the international and national literature on financialization and analyzes the relevance of the debate to the field of urban planning, prioritizing Brazilian issues. We recognize that the literature on financialization has made progress, up to the point that some authors argue that the concept has been hollowed out. However, we believe that there is substantial potential for exploring - conceptually, methodologically and empirically - on-going financialization processes in Brazil, as well as their political limits. We discuss the mechanisms of urban financialization in Brazil, which unfolds in the interconnection of large projects, in state-driven credit mechanisms, and in the transformation of the state and planning. We conclude with suggestions for a research agenda on financialization with relevance to the field of Brazilian urban planning.
\end{abstract}

Keywords: financialization; state; urban planning; spatial scales; austerity. 


\section{Introdução}

Este artigo tem três objetivos. 0 primeiro deles é apresentar uma sistematização da literatura internacional e nacional sobre o fenômeno da financeirização. Nesse sentido, discutimos os diversos esforços teóricos que foram desenvolvidos nos últimos anos. 0 segundo objetivo é analisar a relevância das pesquisas sobre a financeirização para os estudos urbanos e para o campo do planejamento urbano, priorizando as questões brasileiras. Nessa perspectiva, procuramos avaliar se as literaturas internacional e nacional acerca da financeirização proporcionam insights para dialogar com os estudos urbanos e com o campo do planejamento urbano brasileiro. Por fim, o terceiro objetivo é explorar dimensões para uma agenda de pesquisa sobre financeirização com relevância para o campo do planejamento urbano brasileiro.

Presenciamos, principalmente nas últimas duas décadas, um crescimento da literatura sobre a financeirização em áreas de conhecimento como a geografia, a economia política e o próprio planejamento urbano-regional. Essa discussão acerca da financeirização não foi apenas estimulada pelo esgotamento do padrão de regulação do sistema monetário internacional de Bretton Woods, 0 que desencadeou maior volatilidade nas variáveis macroeconômicas-chave (câmbio, juros e preços dos commodities) e a "reemergência" das finanças globais (Helleiner, 1994). A neoliberalização e a reestruturação do Estado e as sucessivas "bolhas" que estouraram no mercado internacional de capitais, a partir da crise das empresas de tecnologia (Nasdaq), e, em 2007/2008, a partir da crise subprime das hipotecas "podres", também impulsionaram 0 debate. 0 próprio campo do planejamento urbano, principalmente com base em temas como os grandes projetos urbanos, a gentrificação e a natureza das rendas fundiárias, analisou, desde os anos 1970, assuntos relacionados com a financeirização sem, no entanto, aprofundar essa agenda específica.

Conforme ressalta Christophers (2015, p. 184), chegou a hora de "fazer um intervalo, respirar, e (re)avaliar cuidadosamente" ${ }^{1}$ a literatura sobre financeirização. Contudo, não apenas na direção que apontamos no primeiro objetivo (que se alinha às ideias do autor supracitado) - no sentido de apontar sobreposições, eventuais modismos em relação às discussões antigas (com "rótulos" diferentes), lacunas e imprecisões nas definições conceituais -, mas também o alinhavando com o segundo objetivo deste artigo , proporciona subsídios para mapear melhor os diálogos entre as diversas vertentes na literatura internacional e nacional sobre financeirização e campo do planejamento urbano.

No caso brasileiro, isso é importante por duas razões. Primeiramente, porque contribui para gerar uma reflexão crítica sobre as dinâmicas socioespaciais, as racionalidades dos agentes públicos e privados e os impasses que cercam a agenda da reforma urbana e da função social da propriedade com possíveis insights a partir da discussão sobre a financeirização. Além disso, porque mobiliza um debate sobre a transformação da própria "práxis urbana" contraditória nas cidades brasileiras.

Assim sendo, o terceiro objetivo deste artigo é explorar as dimensões de uma agenda de pesquisa sobre a financeirização com relevância conceitual e "política" para o planejamento urbano brasileiro. 
Cumpre mencionar que a agenda de pesquisa sobre financeirização é fortemente moldada pela circulação de ideias no âmbito da comunidade acadêmica dos países centrais, em geral, e do bloco anglo-saxão, em particular. Salvo exceções, o debate nas diversas revistas internacionais indexadas não contempla muitas experiências sul-americanas, de modo geral, nem, mais especificamente, as brasileiras. Foge do escopo deste artigo explorar os limites e potencialidades de uma teoria de financeirização com base na noção de Sul Global ou nas especificidades geográficas e históricas da trajetória do desenvolvimento latino-americano e brasileiro. Mesmo assim, nossa análise representa um primeiro passo para situar o debate sobre a financeirização urbana "entre nós", apoiado na premissa da comparibilidade, isto é, reconhecer similaridades em função das interdependências e transformações estruturais que caracterizam o atual quadro da economia mundial, sem, no entanto, perder de vista as especificidades geográficas e históricas que marcam a trajetória das cidades brasileiras (Robinson, 2002).

Após esta Introdução, o artigo estrutura-se em quatro seções complementares. Na primeira, apresentamos uma definição operacional da financeirização e três grandes vertentes presentes na literatura mais recente (economia política; "contabilidade crítica"; financeirização e vida quotidiana). Na segunda, analisamos como essa literatura articula-se com 0 debate sobre as cidades e a (re)produção do espaço urbano-regional. Na terceira seção, exploramos elementos para uma agenda de pesquisa sobre financeirização que articula os debates internacionais e nacionais com o campo do planejamento urbano-metropolitano, com ênfase para a realidade das metrópoles brasileiras. Finalmente, é apresentada uma breve conclusão com base no desdobramento das discussões realizadas.

\section{Origem e principais vertentes no debate teórico sobre financeirização}

Aalbers (2015, p. 214), um dos protagonistas nos debates recentes em torno do tema, define a financeirização de forma elástica:

A crescente dominância de agentes, mercados, práticas, métricas e narrativas financeiros, nas múltiplas escalas, o que tem gerado uma transformação estrutural das economias, das corporações (incluindo instituições financeiras), dos Estados e das famílias. ${ }^{2}$

Referida definição é útil porque mostra a abrangência do processo de financeirização, que mobiliza diversas escalas, agentes (financeiros - não financeiros; públicos e privados), práticas (materiais e discursivas) e institucionalidades na transformação das economias, das corporações e da própria vida quotidiana. Além disso, essa conceituação abre a perspectiva de uma variedade de abordagens. Grosso modo, podemos destacar três grandes vertentes entrelaçadas na literatura mais recente sobre o tema, a saber: (1) marxismo, regulacionismo e economia política; (2) governança corporativa, contabilidade crítica e capitalismo de coupon pool (3) financeirização e a vida quotidiana: economia cultural, performatividade e os estudos sociais sobre as finanças. A seguir, trataremos de cada uma delas. 


\section{Marxismo, regulacionismo e economia política}

A primeira vertente, que rotulamos genericamente como a abordagem da economia políti$\mathrm{ca}^{3}$ tem raízes no marxismo (por intermédio de autores como Hilferding), mas conta também com trabalhos desenvolvidos na tradição da escola de regulação (por intermédio de autores como Boyer, Chesnais), no pós-keynesianismo (com Minsky) e na teoria politica de relações internacionais (com Helleiner).

Independentemente das diferenças entre os autores, essa linha de pesquisa prioriza as grandes transformações macroestruturais que ocorreram no sistema de acumulação (a economia) e no modo de regulação (a atuação do Estado nas múltiplas escalas, a relação salarial, o regime monetário, as formas de competição e de inserção no sistema internacional). A análise sobre a reemergência das finanças globais no pós-Bretton Woods, sob a hegemonia do Estado norte-americano e do capital financeiro, é emblemática. 0 colapso de Bretton Woods implicou na ruptura do sistema de câmbio fixo, o que imediatamente transformou a dinâmica dos mercados de câmbio, de juros e de commodities. Os juros variáveis, a taxa de câmbio flutuante e a reciclagem dos petrodólares nas principais praças financeiras do mundo geraram, nos anos 70, um quadro de grande volatilidade e risco. Ao mesmo tempo, esse cenário, que viria a ser uma tendência, desencadeou oportunidades para capitalizar lucros associados às operações de compra e venda no mercado futuro. ${ }^{4}$

Além disso, a liberalização dos mercados de capitais e a criação de novas engenharias financeiras, como a securitização e a crescente influência dos agentes financeiros sobre o desenho da política macroeconômica de viés monetarista, constituíram um ambiente propício à circulação internacional de fluxos financeiros em escala relativamente inédita. Tal penetração das finanças no mundo industrial-fordista também transformou uma lógica até então pautada por estabilidade e previsibilidade. As finanças e a antecipação de fluxos de renda futura para o presente (a chamada capitalização) facilitaram a reestruturação da economia para um sistema mais flexível, analisado por David Harvey em termos da aceleração de tempo e espaço. A partir desse período, presenciamos a proliferação de projetos e estratégias empresariais marcados por retornos mais rápidos (período de repagamento de investimentos iniciais), obsolescência precoce de investimentos e ativos e ajustes espaciais intensos, envolvendo relocação de plantas industriais em escala global. A teorização sobre o fenômeno de capital switching sinalizou que as sucessivas crises de acumulação no sistema produtivo-industrial (o circuito primário) são temporariamente absorvidas (mas nunca resolvidas) pela circulação do capital no ambiente construído (o circuito secundário). ${ }^{5}$

Na tradição da economia política, a financeirização está umbilicalmente ligada às relações sociais e ao conflito entre o capital e o trabalho. ${ }^{6}$ Por exemplo, a escola da regulação ressalta que a ampliação do acesso a crédito não pode ser dissociada da transformação da própria relação salarial que, ao menos nos países centrais, representava a espinha dorsal durante os anos dourados do fordismo-keynesianismo. Com a crise desse modelo de desenvolvimento, o arrocho salarial, a precarização da oferta de emprego com registro em carteira 
e o recuo do Estado de bem-estar social na provisão de uma série de bens públicos - como moradia e infraestrutura social-urbana - foram acompanhados por uma ampliação dos mecanismos de acesso ao crédito. Nesse cenário, denominado por Crouch (apud Van Der Zwan, 2014 , p. 117) "keynesianismo privatizado" ou "keynesianismo hipotecário", não é o governo, mas o trabalhador quem assume o papel de azeitar o multiplicador de renda e emprego que garanta o crescimento macroeconômico.

No entanto, isso não implicou o esvaziamento do Estado. Rolnik (2015), por exemplo, aponta que a relação imbricada entre a neoliberalização e a financeirização foi articulada por meio de um projeto de "inclusão predatória", que incentivou e democratizou o acesso a diversas fontes de crédito imobiliário e financiamento habitacional, com ênfase nas abordagens orientadas para a demanda via carta de crédito. Diversos países na Europa privatizaram suas companhias habitacionais e transformaram o estoque de aluguel subsidiado por meio de estratégias de ampliação de acesso a fontes de financiamento para a compra da casa própria.

A literatura nacional alinhada de alguma forma a essa vertente (Fiz, 2011; Royer, 2014) discute a trajetória brasileira da política urbana e habitacional, desde os anos 1990, no que diz respeito às relações entre a ampliação do financiamento habitacional, a financeirização e a (des)(r)estruturação do Estado nacional-desenvolvimentista sob a suposta "dominância das finanças" e do rentismo (Paulani, 2011).

Nesse sentido, é importante reconhecer a particularidade da financeirização da economia brasileira, pois esta se desenvolve sobre a base da renda de juros e tem como eixo 0 endividamento público interno ${ }^{7}$ (Bruno et al., 2011). Embora sejam importantes os esforços de periodizar o avanço da financeirização no País e de relacioná-lo com as mudanças no ambiente institucional, entendemos que esses processos não se limitam à dinâmica macroeconômica ou às decisões tomadas nas escalas nacional e supranacional. Em outras palavras, existe o desafio de relacionar como a financeirização condiciona as operações de financiamento e de despesas públicas, modificando as estratégias de diversos agentes, com uma abordagem que seja mais sensível às principais dimensões espaciais: escalas, lugares, redes e territórios. Assim, será possível uma melhor compreensão das relações micro e macro do fenômeno e da evolução de suas geografias históricas no Brasil.

Um relevante ponto de partida seria combinar aspectos quantitativos e qualitativos da financeirização. Embora seja desejável apresentar aspectos mensuráveis da penetração das finanças em diversas esferas da economia, do Estado e da vida quotidiana, o foco da análise não deve se limitar à comparação de índices, mas deve entender como as relações entre os agentes são transformadas em diferentes contextos.

É importante considerar que as diferenças entre o processo de neoliberalização dos anos 1990 - stop and go das políticas habitacionais e da política voltada para a urbanização de assentamentos precários e mudanças contínuas do setor dentro do organograma do governo (Arretche, 1996) - e o projeto social-desenvolvimentista de crescimento econômico com inclusão social do período dos governos dos presidentes Luiz Inácio Lula da Silva e Dilma Rousseff, da primeira década do século XXI, 
foram reais. Mesmo assim, é possível apontar um denominador comum na política federal que foi a procura para novos mecanismos de subsídio e financiamento que pudessem, ao mesmo tempo, focalizar os segmentos populacionais de baixa renda com menor capacidade de endividamento e pagamento - aliviando, assim, o fundo público da responsabilidade pela provisão de moradia para as classes mais abastadas - e fomentar o protagonismo do mercado imobiliário e financeiro na criação de um sistema moderno de intermediação financeira com escala, liquidez e menores taxas de risco para o setor privado.

A literatura brasileira apresenta um balanço desse projeto contraditório. Por exemplo, ao contrário da narrativa constituinte, o Sistema Financeiro Imobiliário (SFI) não proporcionou maior liquidez para o segmento residencial por meio da alocação de "dinheiro novo" do mercado de capitais. Na prática, as sucessivas medidas de flexibilização da regulação permitiram uma confluência entre a esfera pública e a privada, no sentido de que os recursos do criticado sistema paraestatal do Sistema de Financiamento Habitacional (SFH) pudessem ser aplicados na aquisição dos títulos financeiros criados no âmbito do SFI (Royer, 2014; Cagnin, 2012). Na outra ponta da estrutura, as pesquisas apontaram que a focalização dos mecanismos de subsídio e de crédito para a baixa renda, por meio de programas como Minha Casa Minha Vida (PMCMV), mostrou-se desafiadora. Os subsídios diretos e indiretos desencadearam uma dinâmica de capitalização de rendas fundiárias pelos proprietários da terra e pelas incorporadores com efeitos sobre os preços imobiliários, gerando não apenas baixa inserção urbana dos empreendimentos frequentemente implementados em áreas periféricas, mas também um atendimento do déficit habitacional via o programa "de habitação social de mercado" que, para todas as faixas de renda contempladas, ficou aquém do esperado (Rolnik e Klink, 2011; Shimbo, 2012).

De certa forma, a referida literatura crítica sobre o desafio de recortar adequadamente o desenho dos subsídios e dos financiamentos para as camadas menos abastadas durante o período social-desenvolvimentista dos governos Lula e Dilma remete-nos ao debate de Francisco de Oliveira referente ao papel do fundo público, tanto na reprodução do capital quanto na da força de trabalho (Oliveira, 1988). No momento atual essa discussão assume maior complexidade à luz da crescente penetração da "finança" na formulação e implementação das políticas públicas.

\section{Governança corporativa, contabilidade crítica e capitalismo de coupon pool}

Um segundo grupo de pesquisas sobre financeirização, que denominamos aqui "contabilidade crítica", está ancorado na tradição das discussões sobre a governança corporativa. Cabe primeiramente destacar que esta última linha, desde as discussões seminais de autores como Cyert e March (1963), desmistificou a ideia da corporação moderna como um bloco monolítico organizado em departamentos funcionais - marketing, finanças, produção, recursos humanos, etc. - que compartilham informações no âmbito de um processo racional de tomada de decisões em prol do objetivo da maximização dos lucros da organização. $\mathrm{Na}$ prática, os departamentos possuem interesses 
conflitantes, e a corporação moderna é marcada pelas assimetrias de informações e pela racionalidade limitada. Nesse contexto, a melhor estratégia não é a maximização dos lucros, mas um lucro satisfatório.

A teoria do principal-agente carrega esse raciocínio para a análise dos conflitos de interesse entre 0 alto executivo e os acionistas-proprietários no âmbito das corporações financeiras e, particularmente, das não financeiras (Fama, 1970; Froud e Williams, 2002). Os executivos têm agenda própria e nem sempre procuram atender aos interesses dos acionistas por meio da maximização do shareholder value, isto é, a soma dos dividendos e a valorização do preço da ação ao longo do tempo. Portanto, 0 acionista precisa monitorar as atividades do executivo, o que implica custos transacionais. Nesse sentido, as estratégias de remuneração de executivos, por meio de programas de distribuição e compra de ações, representam uma estratégia de aglutinar o executivo em torno da maximização do valor das ações.

A mudança na relação entre acionista e executivo, no sentido de maximizar o shareholder value, gera novas práticas empresariais. Por exemplo, a gestão tende a priorizar resultados no curto prazo, acelerando o payback dos investimentos e mostrando resultados nos balanços financeiros trimestrais que estejam alinhados com as expectativas do mercado. Além disso, shareholder value implica reduzir riscos, priorizando o foco nas atividades centrais e subcontratando atividades periféricas.

Nesse contexto, emergem também novas métricas sintéticas e reconhecíveis para reduzir os custos transacionais para os acionistas monitorarem o alto executivo, como, por exemplo, o lucro líquido sobre patrimônio (uma aproximação da taxa de retorno) e a relação entre o preço das ações e o lucro líquido (como uma espécie de projeção acerca da capacidade de a corporação gerar renda para o investidor).

As análises desenvolvidas na literatura da contabilidade crítica apresentaram uma visão sombria sobre a distribuição funcional de renda (isto é, entre trabalhador e capitalista) no âmbito da corporação, destacando o ônus para o trabalhador comum e os expressivos ganhos para o alto executivo, com os seus interesses agora atrelados à agenda do acionista (Van Der Zwan, 2014). Froud, Johal e Williams (2002) levam essa análise pessimista um passo adiante, quando descrevem o capitalismo de coupon pool (marcado pela transformação de um sistema de intermediação financeira que, por sua vez, apenas articula poupança e investimentos, para um mercado de capitais mais sofisticado, que regula o comportamento de empresas e famílias a partir da securitização, gerando tendências de instabilidade).

Os casos emblemáticos de coupon pool, no qual a condição básica é a destinação de grande parte da poupança de longo prazo em títulos securitizados que criam um fluxo contínuo de recursos nos mercados secundários, são os modelos norte-americano e britânico.

No entanto, a inexistência dessa situação genérica não significa que o capitalismo de coupon pool não possa ser analisado em outros países, como o Brasil. Com efeito, não se trata de um modelo que prevê certos resultados, mas de "uma forma de pensar sobre o que precisa ser investigado e especificado", sendo seus efeitos gerais dependentes de vários elementos como "o tamanho do coupon pool, a escala dos fluxos, as normas e comportamento 
e as regulações que determinam o que famílias e corporações podem e devem fazer" (Froud e Williams, 2002).

No cenário brasileiro, vários pesquisadores desenvolveram trabalhos que dialogaram com a literatura da contabilidade crítica. Por exemplo, a análise de Shimbo (2012) sobre a "Empresa Construtora Pesquisada" virou estudo de caso obrigatório para quem quisesse entender melhor a transformação das relações entre o capital construtor e incorporador e o mercado de capitais, a partir das emissões na bolsa de valores, bem como as repercussões sobre o ambiente construído e o canteiro da obra em termos da padronização dos produtos imobiliários e precarização das relações de trabalho.

Rocha Lima Júnior (2012, p. 17), por sua vez, debruçou-se sobre as decisões equivocadas que foram tomadas pelas construtoras no período de expansão a partir da Região Metropolitana de São Paulo (RMSP) para outras regiões brasileiras por meio da captação de recursos no mercado de capitais. Ressaltou os erros cometidos no sentido de transformar projeção de valor geral de venda utilizada em estudos de viabilidade econômico-financeira em fluxo de caixa realizado e de delegar decisões sobre investimentos para "os jovens analistas planilheiros" (ibid., p. 18).

Sanfelici e Halbert (2015) ampliaram a perspectiva sobre esse período e romperam com a visão dicotômica entre acionista e gerência, traço marcante de algumas abordagens da literatura sobre shareholder value. Os autores discutiram as relações imbricadas entre as construtoras-incorporadoras e o mercado de capitais a partir de um enfoque de circulação de expectativas, normas e convenções, criando "ressonâncias" dentro de uma comunidade profissional composta pelos executivos de construtoras e incorporadoras, analistas, consultores e intermediadores financeiros, gerentes de fundos imobiliários e mídia financeira. Na visão dos autores, em um primeiro momento, foram as próprias construtoras e incorporadoras que disseminaram a narrativa que criou ressonância junto aos agentes do mercado de capitais em torno de uma estratégia expansionista em mercados regionais via captação de recursos e investimento por meio de formação de bancos de terra. A divulgação dos resultados desalinhados com as projeções financeiras iniciais, a partir do período 2010-2011, gerou dissonância nessa comunidade profissional e implicou ajustes em normas e convenções. 0 próprio mercado de capitais, em um processo dinâmico de aprendizagem, reconhecendo as especificidades do mercado do ambiente construído, assumiu agora mais protagonismo no desenho de estratégias mais cautelosas e marcadas pela ênfase na rentabilidade ao invés do crescimento. Cabe destacar que Sanfelici e Halbert analisaram elementos do processo constituinte de financeirização a partir de uma abordagem que também dialoga com a economia cultural e a economia de normas e convenções, que será objeto de análise na próxima seção. Pode-se argumentar que a abordagem da contabilidade crítica se encontra num nível analítico meso e possibilita uma "ponte" entre as contribuições da economia política e da financeirização da vida quotidiana. Em relação aos regulacionistas, por exemplo, ambas estão preocupadas com fluxos macro, formas monetárias, circuitos e setores, mas a contabilidade crítica rejeita o que considera uma visão mecanicista em favor de questões dinâmicas relacionadas a mudanças no comportamento 
(de firmas e famílias), rompendo, assim, com a noção de regime de crescimento ${ }^{8}$ (Froud, Johal e Williams, 2002). Além disso, o ponto de contato com a financeirização da vida quotidiana ocorre na conexão entre as finanças e as massas financeirizadas, que estaria relacionada ao crescimento do investimento em ações pelos fundos de pensão das empresas e a disseminação da casa própria (o que nos EUA e Reino Unido teria ocorrido nos anos 1950 e 1960).

\section{Financeirização e a vida quotidiana:} economia cultural, performatividade e os estudos sociais sobre as finanças

A terceira vertente prioriza a análise da suposta penetração do crédito e das finanças na (re) produção da vida quotidiana via o acesso a diversas formas de (micro)crédito e finanças, ${ }^{9}$ variando de hipotecas e financiamento imobiliário - o que Aalbers (2012) intitula como a emergência das subprime cities - ao crédito ao consumo. 0 recorte implícito na literatura que trata do tema está voltado para a população de baixa à média-baixa renda. Nesse sentido, existe uma complementaridade com a economia política em geral e as vertentes do capital switching em particular, no que diz respeito ao arrocho salarial em tempos de neoliberalização que fez com que as finanças penetrassem com mais facilidade nas estruturas individuais de contenção de risco via planos de seguro de vida e seguro-saúde, planos privados de previdência e de financiamentos de acesso a bens de consumo como carros e eletrodomésticos, entre outros exemplos. Na realidade, o recuo do Estado de bem-estar social e o aperfeiçoamento do mercado de capitais transformaram o próprio indivíduo em um analista que deveria passar a gerenciar os riscos de sua vida como uma espécie de ativo financeiro: "enquanto gerencia ativamente os riscos, o indivíduo investidor pode preparar-se adequadamente para um futuro que nunca é seguro e sempre cercado por incertezas. Consequentemente, a própria vida transforma-se em um ativo que precisa ser gerenciado" 10 (Van Der Zwan, 2014, pp. 112-113).

Um exemplo dessa linha de argumentação é o estudo de Soaita e Searle (2016) sobre os significados da casa própria em termos de cálculos subjetivos acerca de custos e benefícios da propriedade no Reino Unido. Os proprietários, como "investidores", tendem a subestimar os custos nos discursos e metáforas mobilizados, o que gera uma "amnésia da dívida", enquanto superestimam os ganhos por meio de cálculos ilusórios e pouco sofisticados. Esse fenômeno seria socialmente construído pela circulação de narrativas e ideologias congruentes.

Nos governos dos presidentes Luiz Inácio Lula da Silva e Dilma Rousseff, esse debate também se intensificou em função da "bancarização" da população de baixa renda e da ampliação do crédito consignado. Ambos os processos foram impulsionados pelo aumento do salário-mínimo e do emprego com carteira assinada, além da política de formalização de categorias profissionais até então à margem do mercado formal, como os empregados domésticos e as cooperativas de coleta de resíduos sólidos (Costa, 2002).

Ainda no âmbito dessa linha de pesquisa, a economia cultural e os estudos sobre a performatividade representam uma abordagem específica no debate sobre 
financeirização. A ideia da performatividade ganhou destaque a partir do trabalho de autores como MacKenzie e Callon que argumentaram que os modelos econômicos utilizados no mercado financeiro não apenas descrevem a realidade da bolsa, mas transformam as práticas utilizadas pelos operadores na praça financeira e, com isso, o próprio mercado (Callom, 1998; Mackenzie, 2005).

0 conceito transborda para além de modelos econômicos e práticas utilizados pelos operadores financeiros no mercado. Performatividade pode ser relacionada com narrativas, estratégias e práticas materiais, discursivas e "calculistas", de agentes públicos e privados, no sentido de usar modelagens para transformar o próprio espaço urbano (Henrikson, 2009). Essa ampliação do escopo metodológico também permite articular a ideia da performatividade para o campo da economia política e do debate sobre a financeirização como um processo contestado, relacionado com a neoliberalização (Berndt e Boeckler, 2009). Da mesma forma, as métricas financeiras que são objeto das diversas análises, no campo da contabilidade crítica, sobre shareholder value refletem modelagens que podem ser utilizadas não apenas para descrever, mas transformar o mundo e o espaço urbano-regional.

Nesse sentido, uma das aplicações ainda pouco exploradas é a relação entre os modelos ortodoxos da economia financeira e imobiliária utilizados pelas consultorias para descrever e representar a estrutura do espaço urbano-regional e as práticas efetivamente adotadas pelos agentes públicos e privados na elaboração e execução dos instrumentos da política urbana. Por exemplo, o grupo seletivo de escritórios de consultoria desempenha um papel relevante na elaboração de estudos de viabilidade financeiro-econômica e no desenho de parâmetros-chave para programas de parceria público-privada e Operações Urbanas Consorciadas (OUCs) nas cidades brasileiras (por meio de instrumento como a Outorga Onerosa do Direito de Construir - OODC - e Certificados de Potencial Adicional de Construção - Cepac). ${ }^{11} \mathrm{Na}$ prática, como discutiremos adiante, na próxima seção, esses profissionais da consultoria urbana assumem papel importante tendo em vista suas práticas espaciais-calculistas na transformação das cidades e áreas metropolitanas. Alguns autores argumentam que as métricas e as técnicas financeiras utilizadas por esses consultores nos estudos de viabilidade (como, por exemplo, a taxa interna de retorno de um projeto e os modelos de fluxo de caixa descontado) ${ }^{12}$ paulatinamente influenciam normas e convenções que norteiam o desenho da politica de cobrança das contrapartidas a serem pagas pelos empreendedores. McAllister (2017), por exemplo, discute a influência de modelos e consultores no mecanismo de planning gain adotado na Inglaterra, enquanto Klink e Stroher (2017) analisam o papel dos estudos de viabilidade na precificação dos Cepacs. Desse modo, conforme argumenta Muellerleile (2013), o potencial analítico da performatividade torna-se ainda maior quando se contornam algumas de suas tendências a produzirem argumentos aespaciais e apolíticos. Ainda de acordo com esse autor, a análise rigorosa dos mercados financeiros requer entender tanto sua lógica e operações internas como o contexto mais amplo e as relações de poder no qual se inserem e dependem para sua reprodução.

Um aspecto promissor das pesquisas sobre a financeirização é que um número 
crescente de trabalhos procura articular as relações imbricadas entre as três vertentes mencionadas anteriormente no sentido de aperfeiçoar as leituras analíticas sobre esse fenômeno, assim como o seu entrelaçamento com o espaço urbano-metropolitano, aspecto este que será objeto da próxima seção. ${ }^{13}$

\section{A financeirização e as metrópoles}

Segundo Rutland (2010, p. 1167):

Os estudos sobre o re-desenvolvimento do urbano poderiam certamente ganhar algo da literatura sobre a financeirização, desde que os primeiros continuem a tratar não apenas do capital financeiro, mas também dos mecanismos materiais e ideológicos através dos quais a propriedade imobiliária é constantemente transformada em ativo financeiro. ${ }^{14}$

A literatura sobre o "redesenvolvimento do urbano" antecedeu e previu algumas das discussões mais recentes sobre financeirização que apresentamos na seção anterior. Rutland (ibid.), citado acima, por exemplo, argumenta que há mais de três décadas Harvey (1982) foi pioneiro no debate a partir de suas análises sobre as relações entre o empresariamento urbano, os grandes projetos urbanos e a tendência à transformação da terra em ativo financeiro. Mesmo que adote um tom cético acerca de seu caráter inovador, o próprio Rutland reconhece que a literatura recente sobre a financeirização potencialmente agrega valor aos debates existentes sobre a transformação do espaço urbano, desde que aprofunde a análise acerca das condições sobre as quais as cidades e a terra são transformadas em ativos financeiros.

Evoluindo dos temas mais específicos para questões mais gerais e abstratas, apontamos três vertentes entrelaçadas na literatura na qual essa relação entre "o urbano" e o processo de financeirização se tornou objeto explícito do debate:

(1) Grande Projetos Urbanos "2.0" e os novos agentes no circuito imobiliário;

(2) a reestruturação do financiamento público para o desenvolvimento urbano; e

(3) o Estado, o espaço e a "financeirização" do empresariamento urbano.

\section{Grandes Projetos Urbanos "2.0" e os novos agentes no circuito imobiliário}

0 debate sobre grandes projetos urbanos não é recente e, de certa forma, está imbricado com 0 tema da neoliberalização e do empresariamento urbano. ${ }^{15}$ Desde os anos 1980, a literatura no campo da economia política e do institucionalismo crítico tem ressaltado as contradições inerentes associadas às novas formas de planejamento e à gestão via grandes projetos (Swyngedouw, Moulaert e Rodriguez, 2002).

Apesar da riqueza das abordagens e dos estudos empíricos que acompanharam a discussão sobre os grandes projetos urbanos, não houve, paradoxalmente, muitas análises sobre o crescente entrelaçamento do mercado imobiliário com o financeiro. Guironnet e Halbert (2015), por exemplo, argumentam que a ampliação do recorte analítico para os agentes do mercado financeiro desencadeia novas perguntas para a agenda de pesquisa sobre grandes 
projetos urbanos. Quais projetos e estratégias adotados pelos investidores e pelos diversos agentes que atuam no mercado de capitais (analistas, empresas de consultoria financeira, bancos de investimento, agência de avaliação de risco, etc.)? E como esses agentes inserem-se e articulam-se nos grandes projetos urbanos? Como a governança de grandes projetos urbanos e seus resultados são moldados por eles? Em certo sentido, trata-se de uma abordagem relacional para a financeirização, na qual esta só pode ser entendida considerando-se estratégias, fluxos e relações entre os agentes que atuam em várias escalas.

Halbert também procura analisar sob quais condições as estratégias de precificação e capitalização ${ }^{16}$ de rendas futuras associadas ao ambiente construído (moradia, prédios comerciais, redes de infraestrutura, etc.) tendem a transformar o espaço urbano-regional em um Portifólio de Ativos Rentáveis e Comercializáveis (Parc). Sendo que, por rentáveis, têm-se uma combinação de rendas periódicas - fixas ou variáveis - com ganhos de capital e, por comercializáveis, têm-se ativos que podem ser comercializados em mercados secundários Tradeable Income Yielding Assets (Guironnet e Halbert, 2015). Da mesma forma que a financeirização influenciou o relacionamento dos acionistas com o alto executivo dentro das corporações, a constante procura pelo "Parc" no ambiente urbano muda a governança territorial que articula público e privado, que será cada vez mais moldada por lógicas, métricas e práticas do capital financeiro. Leyshon e Thrift (2007, p. 98), por exemplo, argumentam que:

0 capital financeiro depende da constante procura ou construção de novos fluxos de renda associados aos ativos, normalmente por meio de um processo de agregação que permite, apenas após sua consolidação, que a especulação ocorra. ${ }^{17}$

Os referidos autores proporcionam exemplos desse processo de produção e circulação de rendas em torno do ambiente construído nas cidades, alguns mais conhecidos (mercado secundário de títulos hipotecários, transformação de aluguéis em títulos de recebíveis de alugueis, etc.) e outros menos disseminados no cenário brasileiro.

As parcerias público-privadas para 0 desenho, financiamento, construção e operação de projetos de infraestrutura urbana para execução do setor privado em troca de pagamento de juros e de amortizações ao longo da vida útil do projeto pelo setor público talvez seja um exemplo menos conhecido. Mais especificamente, a capitalização e a securitização dos recebíveis de juros e amortizações nessas parcerias permitem que o setor privado assuma, em tempo real, novos compromissos para diversificar e ampliar a escala das operações e também dos riscos. No mundo anglo-saxão, a penetração dessa lógica financeira tem gerado contradições no planejamento e na gestão públicos das redes de infraestrutura no anseio de satisfazer às expectativas dos investidores por meio de cortes na manutenção, aumento de tarifas e enxugamento de quadros profissionais essenciais.

A financeirização via grandes projetos urbanos não ocorre apenas por meio "da finança" (Paulani, 2011). Kaika e Rugierro (2016), por exemplo, descrevem o caso emblemático de crise e reestruturação da fábrica da Pirelli com o Projeto Techno-City, na Região 
Metropolitana de Milão. A experiência mostra que, no bojo da crise fordista que acometeu o parque industrial italiano nos anos 1980, a elite industrial literalmente:

largou a sua prática tradicional no sentido de tratar os terrenos industriais como condição de produção, que iriam depreciar ao longo do tempo, e reinventou a sua propriedade fundiária como 'um puro ativo financeiro' (Harvey, 1982, p. 347), que agora poderia ser precificado no balanço da empresa de acordo com 0 aluguel que este potencialmente poderia receber no mercado imobiliário. (Kaika e Rugierro, 2016, p. 8)

Desse modo, capitalizando as rendas fundiárias futuras, que também foram impulsionadas pelos parâmetros urbanísticos mais flexíveis adotados pelo planejamento urbano no contexto do projeto estratégico Projeto Techno-City, a empresa conseguiu melhorar seus balanços e demonstrações financeiras perante o mercado.

0 debate brasileiro sobre a financeirização via grandes projetos urbanos foi particularmente recortado para a análise das consequências socioespaciais adversas desencadeadas pelas Operações Urbanas Consorciadas (OUCs) com Cepac. Processos de gentrificação e expulsão dos assentamentos precários, seletividade dos investimentos em termos de privilegiar determinados setores (rodovias e mobilidade privada) e classes sociais foram os aspectos mais ressaltados na literatura voltada ao tema (Fix, 2011).

No entanto, salvo poucas exceções, as operações não foram analisadas com base em um prisma que também lançou luz sobre as racionalidades dos investidores e agentes financeiros (Sandroni, 2010; Maleronka, 2010). Emerge daí um questionamento: quais foram 0 processo constituinte e "a técnica" para definir determinado preço mínimo dos Cepac que garantisse viabilidade econômico-financeira, 0 desenho adequado dos perímetros da área e a quantidade e qualidade dos investimentos públicos previstos para a OUC (Operação Urbana Consorciada)? Em sua análise sobre o projeto estratégico do Porto Maravilha no Rio de Janeiro, Pereira (2016) mostra que as OUCs via Cepac não podem ser dissociadas de uma avaliação da modelagem institucional e financeira em geral, e de suas relações com o desenho e a execução dos mecanismos de financiamento nacional para o ambiente construído via fundos semipúblicos, como o Fundo de Garantia do Tempo de Serviço (FGTS) e, recentemente, o Fundo de Investimento do Fundo de Garantia do Tempo de Serviço (FI-FGTS) em particular. Essas relações entre financiamento público do desenvolvimento urbano e a financeirização é objeto da próxima seção.

\section{A reestruturação do financiamento público para o desenvolvimento urbano}

A financeirização requer compreensão de mecanismos de crédito e financiamento público para o ambiente construído, em geral, e os entrelaçamentos dos recursos públicos e privados, em particular.

0 ambiente institucional norte-americano, marcado pela disseminação das parcerias público-privadas na infraestrutura urbana e pelo acesso direto das cidades ao mercado de capitais em tempos de austeridade fiscal, 
representa terreno particularmente fértil para o debate.

Ashton, Doussard e Weber (2016), por exemplo, analisam as concessões de infraestrutura urbana a partir das relações financeiras imbricadas entre estado local e concessionário (entanglement) que transbordam o momento inicial da assinatura dos contratos. A abordagem desses autores lembra o approach teórico relacional de escalas e do Estado (Jessop, 2008) que procura analisar, ao longo da vida útil das parcerias público-privadas, os projetos e as estratégias dos setores público e privado em relação ao gerenciamento de riscos e eventos não previstos na assinatura dos contratos, bem como suas repercussões sobre a política urbana e a viabilidade econômico-financeira dos empreendimentos privados:

As complexidades associadas às concessões da infraestrutura sugerem que é preciso ampliar nossa perspectiva no sentido de incorporar as dimensões locais da financeirização. Mais notadamente, considerando o papel significativo dos governos locais na criação desses mercados, as teorizações sobre financeirização em escala local deviam funcionar, ou inspirar-se, nas teorias sobre o Estado. (Ashton, Doussard e Weber, 2016, p. 1386) ${ }^{18}$

Com efeito, o estudo da financeirização da infraestrutura urbana, apesar de ter avançado relativamente menos no que se refere aos trabalhos mais difundidos sobre a financeirização da terra e da propriedade imobiliária, tem muito a contribuir com os estudos acerca da emergência do poder da finança global no ambiente construído. As inegáveis similaridades operacionais e cronológicas reforçam a trajetória imbricada entre esses setores. Segundo
Lorrain (2011), a liberalização das indústrias de rede teve papel fundamental como catalizador da financeirização da arena urbana, abrindo território (e mercados). 0 autor argumenta que até os anos 1980 não eram os banqueiros quem "criavam as cidades", mas "os proprietários de terra, incorporadores, companhias de construção, frequentemente o Estado, às vezes os habitantes, e, apenas raramente, os banqueiros" (ibid., p. 50). A privatização das indústrias de rede nos anos 1990 teria sido essencial para essa mudança no poder sobre as cidades, um poder que influencia a política urbana ao "monitorar e avaliar um grande número de projetos, e porque seus instrumentos e critérios associados foram amplamente disseminados e têm impactos além de sua esfera de intervenção direta, introduzindo uma mudança nos tipos comuns de análise" (ibid., p. 48). Se a ampliação dos projetos urbanos enfrentava ainda barreiras pelo longo prazo de maturidade e localização física, as finanças romperam esse limite e inseriram novas formas de pressão do mercado sobre as políticas públicas, em ambientes institucionais diferenciados.

Na realidade, a capacidade de as cidades norte-americanas emitirem títulos no mercado de capitais gera um cenário específico. Peck e Whiteside (2016), por exemplo, analisam o caso "não tão especial" da cidade de Detroit, na perspectiva histórica de financeirização da governança urbana nos EUA, culminando na falência em 2014/2015 e no subsequente plano de ajuste fiscal que reenquadrou a gestão da cidade de acordo com os padrões do mercado de capitais. De um lado, a cidade, pressionada pela desindustrialização, pelo esvaziamento de sua base tributária e pelas políticas federais de austeridade fiscal, que desencadearam um 
protagonismo municipal no mercado de capitais por meio de sucessivas emissões de títulos de dívida; de outro, a penetração de lógicas e métricas do mercado de capitais que evoluíram no sentido de disciplinar a governança em escala local.

0 mercado de crédito e de títulos municipais abriu outras perspectivas para a financeirização avançar em escala local nos EUA. Exemplo emblemático foi o mecanismo de Tax Increment Financing (TIF), que se disseminou a partir das primeiras experiências em Chicago (Weber, 2010). O TIF prevê o desenho de um grande projeto urbano dentro de uma área degradada e/ou com problemas de esvaziamento econômico, com delimitação do perímetro. 0 instrumento permite capitalizar o aumento projetado da base tributária na área delimitada para que o município possa, em seguida, acessar o mercado de crédito em condições mais favoráveis. ${ }^{19}$ A ferramenta não apenas consolidou uma nova competência e habilidade profissional para as prefeituras - o consultor-especialista que desenha, monitora e avalia as operações do TIF -, mas também reforçou as interdependências entre a governança e o planejamento urbanos e o mercado de capitais.

No entanto, em contextos institucionais diferentes dos EUA, a penetração da financeirização por meio da reestruturação do crédito e do financiamento públicos não ocorreu da mesma forma. No cenário europeu, por exemplo, o esvaziamento do keynesianismo espacial implicou estratégias de privatização do estoque habitacional público, combinado com a transformação do aluguel social em casa própria via sistemas de financiamento privado. De certa forma, a neoliberalização preparou o terreno para a inserção dos países alinhados com o regime do keynesianismo espacial no circuito financeirizado (Rolnik, 2015).

No arcabouço institucional do federalismo fiscal brasileiro, os municípios também não têm capacidade para emitir títulos da dívida no mercado de capitais. Portanto, diferente do contexto anglo-saxão, as relações entre crédito e financiamento públicos para o desenvolvimento urbano e a financeirização não são mediadas por intermédio de um mercado de capitais nos quais se emitem e comercializam títulos da dívida municipal. Na realidade, conforme argumenta Royer (2014), na análise do entrelaçamento entre o FGTS e o sistema de financiamento imobiliário, a procura pela construção dos Parcs no Brasil ocorre de formas diferenciadas, por exemplo, por meio de projetos e estratégias que captam e transformam os próprios fundos (semi) públicos. Marques (2016) lança mão de argumentos semelhantes sobre a relação entre financeirização e a apropriação do fundo público. Além disso, a ausência de um mercado para títulos municipais obriga abrir a perspectiva conceitual para a aproximação entre as diversas estratégias (públicas e privadas) de financeirização, a atuação territorial do Estado e as formas de regulação e intervenção urbanas no espaço.

\section{Estado, o espaço e a "financeirização" do empresariamento urbano}

Essa vertente do debate tem um recorte mais abrangente, pois relaciona grandes projetos, recursos e financiamentos em uma perspectiva de financeirização que contempla a transformação do Estado e do próprio planejamento urbano. Conforme mencionamos 
anteriormente, a teoria da regulação e a economia política geraram insights sobre as diversas trajetórias de neoliberalização dos espaços e da variedade de formas de empresariamento urbano. No entanto, até recentemente, essa literatura não aprofundou a análise das relações imbricadas entre o capital financeiro e a financeirização, de um lado, e a transformação da governança e do planejamento urbanos, de outro (Klink e Denaldi, 2014 e 2015). A esse respeito, cumpre mencionar que um conjunto mais recente de contribuições começa a preencher a lacuna.

Ecoando a descrição de Hall (1995) sobre o empreendedorismo urbano dos anos 1970 em termos de um processo de "virando o planejamento de ponto cabeça", o tema recorrente agora gira em torno de como o planejamento urbano se "descontextualiza" sob influência da financeirização e das estratégias do capital financeiro. As cidades em processos de reestruturação produtiva continuam um objeto privilegiado das discussões.

Savini e Aalbers (2015), por exemplo, discutem o projeto de reconversão da área de uma antiga fábrica siderúrgica, na cidade fordista de Sesto San Giovanni, localizada no cinturão industrial no nordeste da Região Metropolitana de Milão. A partir da venda da área pela empresa Falck, em 2000, uma incorporadora local comprou o terreno com empréstimo bancário e desenvolveu um primeiro projeto prevendo usos residencial e comercial. As sucessivas crises, falências corporativas e transações de compra e venda da área desencadearam um aumento de escala e complexidade do projeto em termos da estrutura acionária-proprietária (envolvendo holdings de investidores internacionais além dos agentes locais), dos riscos e expectativas de retorno dos agentes envolvidos. A cada etapa dessa sequência, a engenharia financeira encontrava uma forma de repassar as dívidas e os compromissos para o próximo investidor. 0 impasse em torno da área fez com que o planejamento urbano da cidade de Sesto San Giovanni ficasse entrelaçado com a dinâmica dos agentes financeiros e imobiliários, procurando a captação de uma parcela das rendas fundiárias a partir do aval e da aprovação de um projeto que já se desenraizou dos interesses locais:

0 governo local tornou-se crescentemente dependente da realização da taxa de retorno do projeto; a programação do projeto virou instrumental para a necessidade urgente de liberar o capital para a circulação, ao invés de desempenhar papel de instrumento para responder às demandas locais. A regulação local de zoneamento não freou o gerenciamento especulativo da terra pelos diversos proprietários financeiros, mas, ao contrário, permitiu que a expectativa referente à produção imobiliária aumentasse. (Aalbers, 2015, p. 13) ${ }^{20}$

Na mesma linha, Guironnet, Attuyer e Halbert (2016) analisam a experiência de Saint-Quen, uma pequena cidade de perfil industrial na periferia de Paris administrada por um governo local progressista. Os autores descrevem a perda da capacidade de o governo local resistir às expectativas dos investidores na negociação de um grande projeto urbano de reconversão territorial-industrial. Os investidores acabavam assumindo a liderança na definição do perfil da operação urbana, por exemplo, por meio do fomento de um padrão de homogeneização e aumento de escala dos projetos (em detrimento do uso misto e projetos menores) 
e restringindo inquilinos com um perfil mais arriscado (como, por exemplo, pequenas empresas de base tecnológica e de capital de risco). É notável que esta última orientação contrariava a própria narrativa e estratégia da cidade no sentido de fomentar uma nova economia urbana de conhecimento.

A economia criativa, o empresariamento urbano e a financeirização estão umbilicalmente ligados na experiência do projeto estratégico "22@Barcelona", que ocorreu no bojo da boIha imobiliária espanhola até 2007 (Charnock, Puercell e Ribera-Fumaz, 2014). Esses autores descrevem a estratégia discursiva subjacente ao projeto "22@Barcelona". Enquanto a narrativa oficial era de transformar o distrito fordista de Poblenou em uma nova economia local baseada na inovação e no conhecimento, na prática, esse projeto serviu aos interesses do mercado imobiliário e financeiro e, via 0 aumento da base tributária, à própria prefeitura.

Os estudos de caso citados ilustram como o poder público passa a atuar em estratégias de maximização das rendas da terra e como as relações de poder na implementação dos projetos de desenvolvimento urbano têm sido deslocados em favor dos investimentos financeiros ao longo das frequentes mudanças de usos.

No entanto, cabe ressaltar que a financeirização do planejamento em escala local representa um processo contestado. Não apenas a própria literatura brasileira (Fix, 2011), mas o debate internacional mostra crescente interesse e preocupação com os projetos e estratégias contra-hegemônicas em várias cidades do mundo. Fields (2014), por exemplo, apresenta o papel do "planejamento subversivo" das comunidades em um cenário adverso do avanço dos fundos de investimentos imobiliário sobre o setor de aluguel social na cidade de Nova York. As comunidades nova-iorquinas não apenas contestaram, mas desenvolveram uma práxis alternativa a partir de: estratégias de comunicação com contranarrativas críticas sobre o papel dos fundos imobiliários; coleta de dados e elaboração de indicadores sobre as práticas financeiras predatórias dos fundos em propriedades alugadas (reduzindo manutenção abaixo dos padrões formais, entre outros exemplos); e a reconstituição dos espaços de financeirização, apontando os altos valores de aluguel utilizados pelos fundos na sua comunicação com os investidores e inconsistentes com a capacidade de pagamento no segmento do aluguel social (ibid., pp. 152-159).

\section{A financeirização urbana. E o planejamento urbano (brasileiro) com isso?}

Conforme mencionamos no início deste artigo, Christophers (2015) tece seus argumentos em torno dos limites do conceito de financeirização, sejam tais limites analítico-teóricos, sejam os recortes temporais e/ou espaciais estreitos que foram adotados nas análises. No que se refere ao primeiro aspecto, o autor pontua que uma parcela expressiva da literatura apenas retoma e atualiza aspectos já tratados na literatura mais antiga sobre a globalização financeira. Além disso, na maioria das vezes, 0 recorte temporal-espacial dos debates refere-se ao mundo anglo-saxão no cenário pós-Bretton Woods, limitando a aplicabilidade das afirmações para outros contextos. 
Talvez o argumento mais interessante desse autor seja que o debate sobre a financeirização, de forma paradoxal, perdeu relevância política porque, na maioria das vezes, priorizou investigar as consequências contraditórias, no sentido de penetrar com seus tentáculos na lógica do mundo não financeiro, sem aprofundar a análise sobre o que é a financeirização e seu processo constituinte. Isso requer deslocar o debate do tema de financeirização (de-financialization) para os mecanismos subjacentes ao mundo das finanças, do financiamento e do crédito:

financeirização representa uma crítica limitada no sentido que ela apenas critica o que o mundo das finanças faz - particularmente em outras esferas - onde seus tentáculos esticam-se, quais os constituintes-sujeitos que acabam sendo embrulhados e entrelaçados e quais são as lógicas não financeiras adulteradas - e não o que ele é [...]. (Ibid., p. 232) ${ }^{21}$

Não obstante a relevância das referidas críticas, essas não invalidam explorar elementos de uma agenda de pesquisa "de segunda geração", com recortes específicos para países emergentes como Brasil e com relevância para o campo de planejamento. Essa agenda não analisa apenas consequências e efeitos, mas também a própria natureza da financeirização. Pois, antes de a financeirização "esticar os seus tentáculos", ela precisa emergir num processo constituinte cuja análise, para o caso dos países emergentes com mercados de capitais menos consolidados, assume ainda maior relevância. Dessa forma, uma agenda de pesquisa dessa natureza assume - ao menos potencialmente - relevância política, isto é, capacidade transformadora, no sentido de compreender melhor a dinâmica da moeda, do crédito e das finanças, bem como questionar o crescente entrelaçamento de suas lógicas com a espacialidade do Estado, o planejamento urbano-metropolitano e a (re)produção do espaço urbano e da própria vida.

Nessas notas finais, exploramos duas dimensões para essa agenda numa perspectiva geográfica e histórica que reconheça as especificidades da trajetória do desenvolvimentismo brasileiro:

(1) Estado, Fundo Público e "os espaços e as escalas constituintes" da financeirização urbana

Em outras ocasiões exploramos o potencial de uma abordagem relacional da escalaridade e espacialidade do Estado para superar uma leitura "fetichista" dos instrumentos urbanistas e dos impasses que cercam o projeto redistributivo da reforma urbana (Klink e Denaldi, 2015; Brajato, 2015). Na referida leitura, esses impasses relacionam-se com a ausência da autoaplicabilidade dos instrumentos urbanísticos do Estatuto ou, nessa mesma lógica, com a falta de empenho das administrações locais em efetivamente aplicá-los.

A chave teórica alternativa que apresentamos para a leitura dos impasses da reforma urbana e do "urbanismo progressista" ancora a avaliação dos instrumentos urbanísticos em uma perspectiva mais ampla, dialogando com a atuação do Estado - nas múltiplas escalas assim com projetos e estratégias (materiais e imateriais) adotados pelos demais agentes que influem no desenho e na implementação da política urbana. De acordo com essa perspectiva, a maneira pela qual os instrumentos "progressistas" - como Zonas Especiais de Interesse Social (Zeis), Parcelamento, Edificação e Utilização Compulsórios (Peuc), Imposto 
Predial e Territorial Urbano (IPTU) progressivo no tempo, etc. - e market friendly - como a OUC - são desenhados e implementados é reflexo das disputas multiescalares dos agentes públicos e privados sobre a organização e atuação territorial do Estado por meio de projetos e estratégias de financiamento e de regulação.

Existe uma perspectiva promissora para articular essa leitura alternativa sobre os impasses do planejamento progressista, influenciada pela economia política, pelo regulacionismo e pela teoria relacional do Estado, com os debates sobre a financeirização. Mais particularmente, no caso brasileiro, isso remete ao papel estratégico do fundo público e da regulação num cenário institucional ainda marcado pela baixa penetração das finanças imobiliárias e pela ausência do mercado de capitais e mercado secundário consolidados. Pois, nesse cenário específico, a "constante procura ou construção de novos fluxos de renda associados aos ativos" que podem ser capitalizados (Leyshon e Thrift, 2007, p. 98) a partir da penetração das lógicas e métricas financeiras tendem a ocorrer por meio da articulação de projetos e estratégias que mobilizam, nas múltiplas escalas, 0 próprio planejamento e a atuação territorial do Estado. Numa análise mais recente sobre o papel "dos capitais urbanos", Eduardo Marques relativiza a relevância da tese norte-americana das growth machines imobiliárias, impulsionadas pelas coalizões dos governos locais com as construtoras-incorporadoras em torno dos grandes projetos de renovação urbana, e ressalta a centralidade dos fundos públicos:

se existe alguma máquina nas coalizões urbanas do Brasil, ela está mais ligada à execução de obras e à contratação de serviços do que à captura de valorizações fundiárias produzidas por políticas. (Marques, 2016, p. 30)

No entanto, a partir da premissa da variedade das estratégias (materiais e imateriais) de transformar ativos e propriedades em fluxos de renda capitalizáveis - terra, dívida pública, fundos semipúblicos, como FGTS, conhecimento, etc. - não há, necessariamente, uma contradição entre a procura por valorização imobiliária e por obras e contratos públicos, que são ambos mediados pelo Estado.

A atual conjuntura brasileira, de baixo crescimento econômico, de uma nova rodada de recuo do Estado e de austeridade fiscal, abre uma nova fase para esse tipo de abordagem e de linha de pesquisa que articula as diversas vertentes e escalas da literatura sobre a financeirização (economia política, contabilidade crítica e estudos sociais de finanças) com os estudos urbanos. Em outras palavras, acreditamos que essa agenda tenha o potencial de catalisar o diálogo, pouco praticado nos estudos urbanos brasileiros, entre reestruturação espacial do Estado no período recente (neoliberalização) e financeirização.

Cumpre lembrar que a austeridade é aplicada em configurações já neoliberalizadas de poder do Estado, o que reforça a dinâmica dialética dos momentos destrutivos e construtivos do neoliberalismo (Peck, 2012). Com efeito, não se trata de um mero retorno do neoliberalismo destrutivo (roll back) do início dos anos 1990, pois seu alvo não são apenas aqueles mais tradicionais (direitos trabalhistas, políticas industrial e social), mas também elementos da fase adaptativa e criativa (ro/l out) presentes no novo desenvolvimentismo (Programa Minha Casa Minha Vida - PMCMV, Programa de 
Aceleração do Crescimento - PAC, valorização do salário-mínimo e do crédito, aperfeiçoamento dos mecanismos de coordenação interfederativa, reforço do aparato institucional do Estado). Estamos, portanto, diante de um roll back do roll out (ibid.).

A política de austeridade em andamento no Brasil não representa um momento cíclico, mas um processo cumulativo de incapacitação do Estado, que se mesclará, hibridizará e evoluirá a partir do choque com a paisagem geoinstitucional herdada e com os experimentos regulatórios pró-mercado já implementados - ou tentados -, assumindo características materiais e discursivas peculiares (Barcellos de Souza, 2015).

No que tange mais especificamente à austeridade urbana, a tendência é que se produza uma forma particular e também socialmente regressiva de política escalar, "com as cidades na ponta" (Peck, 2012). A política de austeridade apresenta-se como uma "estratégia de deslocamento do neoliberalismo (do mercado para o Estado, das elites para os marginalizados e do governo federal para os governos estaduais e municipais)" (ibid., 2013, p. 19) e é sob esse ângulo que seus efeitos deverão ser sentidos e estudados no contexto brasileiro. Portanto, as formas da austeridade urbana e as "entradas e entraves" com os quais os capitais financeiros deparam-se na circulação pelo ambiente construído se entrelaçam com o processo de reestruturação do arcabouço institucional que norteia o planejamento urbano-metropolitano no País, que será objeto do próximo ponto.
(2) Financeirização, reforma e contrarreforma urbanas em tempos de austeridade fiscal

A análise preliminar do processo de reestruturação do arcabouço institucional referente a planejamento e financiamento das áreas metropolitanas brasileiras aponta para duas tendências. A primeira diz respeito à ausência de fundos nacionais que projetam - por meio de fórmulas preestabelecidas - o compartilhamento de recursos (não) tributários em bases transparentes e previsíveis para as áreas metropolitanas. A segunda é a emergência de um padrão de financiamento mais flexível, marcado pela presença de mecanismos como a parceria público-privada (tanto no desenho quanto na execução de políticas urbanas) e a operação urbana consorciada, entre outros exemplos. 0 Estatuto da Metrópole, uma espécie de reescaIonamento do próprio Estatuto da Cidade para a dimensão metropolitana, reforça esse cenário marcado pela reestruturação regulatória em tempo de austeridade fiscal. A lei não prevê um fundo metropolitano, que foi vetado no processo de aprovação pela presidente Dilma Rousseff. As únicas fontes de recursos previstas pela lei apontam para o papel estratégico do setor privado no financiamento da cidade via a constituição das Operações Urbanas Consorciadas interfederativas e as parcerias público-privadas. De certa forma, a lei sinaliza novos tempos a partir da transformação de um cenário de "recursos sem planejamento" (primeira década de 2000) para um de "planejamento sem recursos" na metrópole. 0 cenário abre uma nova disputa entre os agentes (públicos/ privados; financeiros/não financeiros) sobre 
o fundo público. Na análise dessas disputas, ressaltamos dois aspectos para a agenda de pesquisa sobre financeirização com relevância política para o campo de planejamento urbano-metropolitano.

Primeiramente, ao contrário do cenário internacional, não produzimos, entre nós, muitas pesquisas sobre as parcerias público-privadas e as transformações no financiamento das redes de infraestrutura urbana, como, por exemplo, o saneamento ambiental (Moreira, 2008). Isso surpreende, principalmente à luz das rápidas transformações no arranjo institucional e financeiro que ocorreram nos últimos anos nesses setores. 0 caso da Região Metropolitana de São Paulo é emblemático. No ano 2002, a Companhia de Saneamento Básico do Estado de São Paulo (Sabesp) emitiu ações no mercado de capitais enquanto acirrou as disputas com as companhias municipais em torno da tarifa de água cobrada e do tamanho da dívida dos municípios junto a ela. Em novembro do ano 2015, o serviço municipal de saneamento ambiental de Santo André (Semasa) apresentou requerimento de instauração de inquérito administrativo para apuração de infrações de ordem econômica junto ao Conselho Administrativo de Defesa Econômica (Cade), acusando a Sabesp de lançar mão de práticas monopolistas por meio de margin squeeze, isto é, de praticar preços abusivos juntos às companhias municipais. ${ }^{22}$ As relações entre os acionistas e 0 alto executivo numa empresa pública como a Sabesp, registrada na bolsa de valores de Nova York, assim como as suas estratégias junto às empresas municipais e à qualidade de serviços e às tarifas praticadas junto aos "principais", isto é, os consumidores de água na Região Metropolitana, abrem uma perspectiva promissora para ampliar as pesquisas sobre a financeirização urbana para além do prisma dos estudos imobiliários-habitacionais.

Em segundo lugar, a análise das operações urbanas consorciadas não apenas requer recortar as consequências contraditórias sobre as populações menos abastadas, mas também o próprio processo constituinte dessas mesmas em termos do desenho físico (o tamanho da área de intervenção; o perfil dos investimentos e dos bens públicos a serem providenciados, como habitação de interesse social e áreas públicas) e financeiro (o preço mínimo dos certificados (epac versus o custo das obras), assim como a governança das operações via prefeitura, empresa pública de capital misto ou outros arranjos institucionais.

Quais serão, então, os reais limites e as potencialidades para o projeto de financeirização urbana avançar por meio de parcerias público-privadas, OUCs e Grandes Projetos Urbanos, considerando as especificidades brasileiras e as experiências mais recentes que vêm ocorrendo em um contexto de estagnação da macroeconomia? Por exemplo, o caso da OUC do Porto Maravilha no Rio de Janeiro, marcada pela captação do fundo semipúblico via investimentos do FGTS, pela transferência de ativos fundiários estatais e pela injeção de recursos públicos adicionais para cobrir os déficits associados ao descompasso entre as expectativas dos investidores e os resultados efetivados alcançados numa economia estagnada, representa uma nova face de um velho padrão? (Pereira, 2016).

As contradições na OUC do Rio de Janeiro também remetem à necessidade de mobilizar chaves teóricas complementares para explorar o descompasso entre a "financeirização 
ideal" e a "efetivamente existente", que, no caso brasileiro, parece recortado para captação e capitalização de rendas futuras associadas ao próprio fundo público (Marques, 2016). Compreender melhor as especificidades e contradições dessas relações imbricadas entre Estado, planejamento urbano e capital financeiro no caso específico do Brasil requer também apreender melhor modelos, metáforas, narrativas e ideologias que circulam na comunidade profissional de planejadores urbanos, analistas e consultores financeiros, bancos de investimento e construtoras, entre outros agentes (Sanfelici e Halbert, 2015). Nesse sentido, reconstituir as relações entre a moeda, o crédito, as finanças, os fluxos financeiros e a variedade de estratégias de mercantilização da cidade no contexto da Contrarreforma Urbana representa ferramenta essencial para reconstituir os espaços da financeirização e apontar caminhos para um planejamento urbano alternativo, "subversivo" em relação à naturalização de um projeto da cidade para o lucro e não para as pessoas (Brenner et al., 2011).

\section{À guisa de uma conclusão}

Este artigo partiu da premissa de que, embora o debate sobre financeirização apresente alguns sinais de esgotamento em certos círculos acadêmicos no mundo anglo-saxão, seu potencial de exploração conceitual e empírica na realidade urbana brasileira ainda está distante de ser realizado. Foram apresentadas três vertentes de pesquisa comumente associadas à financeirização (economia política, contabilidade crítica e financeirização da vida quotidiana) e indicados diálogos existentes e possíveis com base na literatura nacional. Apesar dos avanços significativos em várias frentes de pesquisa, argumentou-se que o campo do planejamento urbano no Brasil teria muito a ganhar com uma abordagem que tentasse um diálogo mais aberto entre os principais conceitos apresentados. Foge do nosso objetivo, neste trabaIho, propor uma teoria sobre a financeirização no capitalismo urbano periférico. Não obstante, parece óbvio que a financeirização no Brasil segue trajetórias particulares - em termos de volumes, processos, temporalidades, instituições, espacialidades, etc. E, mais importante que buscar sua relevância em termos de dinamismo da securitização e dos mercados secundários, é entender sua articulação com o fundo público e com a reestruturação da espacialidade e escalaridade do Estado.

Nesse sentido, pretendemos propor uma agenda de pesquisa ao sistematizar as principais contribuições e inovações presentes na literatura internacional e apontar pontos de entrada com a realidade e os problemas urbano-metropolitanos brasileiros, diante da complexidade de sua reestruturação setorial, espacial e escalar e das contradições da sua reforma urbana (incompleta). 


\section{Jeroen Klink}

Universidade Federal do ABC, Centro de Engenharia, Modelagem e Ciências Sociais Aplicadas. Santo André, SP/Brasil.

jeroen.klink1963@gmail.com

\section{Marcos Barcellos de Souza}

Universidade Federal do ABC, Centro de Engenharia, Modelagem e Ciências Sociais Aplicadas. Santo André, SP/Brasil.

marcos.barcellos@ufabc.edu.br

\section{Notas}

(1) Tradução nossa, do original: "[...] now is the time, [...] to pause, breathe in, and carefully (re) evaluate".

(2) Tradução nossa, do original: "the increasing dominance of financial actors, markets, practices, measurements and narratives, at various scales, resulting in a structural transformation of economies, firms (including financial institutions), states and households".

(3) Seguindo Aalbers e Christophers (2014), adotamos três premissas para classificar a variedade de abordagens dentro do campo da economia política, quais sejam: (1) a prioridade para questões relacionadas com a produção e circulação de valor e renda; (2) as relações entre classes sociais; e (3) a ideologia.

(4) O mercado futuro centraliza contratos que proporcionam direito de compra e vendo no futuro de mercadorias (commodities, produtos agrícolas, moedas etc.) a preços pré-fixados no presente.

(5) As análises mais recentes sobre o processo de capital switching e a crise hipotécaria mostram que o capital financeiro foi instrumental na constituição de relações imbricadas entre o circuito secundário e o terciário (relacionado com a reprodução da vida via os planos de aposentadoria, de previdência e de saúde, entre outros exemplos). A bolha imobiliária nos EUA desencadeou um aumento de endividimento hipotecário da população mais vulnerável, que utilizou os recursos emprestados para complementar planos privados de aposentadoria e de saúde (Aalbers, 2008).

(6) O campo da economia política aqui discutido apresenta desdobramentos em diversas direções, como nos debates sobre globalização e neoliberalismo, e não implica exclusivamente em abordagens sobre a financeirização. Os conceitos mais comumente presentes nesta tradição relevantes para este trabalho são: a existência de um regime de finance led growth, a penetração do capital a juros e do rentismo em diversas esferas da vida econômica e social ou a observância de lucros cada vez maiores através de canais financeiros em detrimento da produção e do comércio.

(7) De início, já há aqui uma diferença estruturante em relação às economias desenvolvidas, em que "a financeirização tende a se desenvolver através do endividamento privado e sob taxas reduzidas de juros, pois é o mercado de capitais o lócus da revalorização rentista" (Bruno et al., 2011, p. 731). 
(8) O capitalismo de coupon pool é considerado um "não-sistema", que se move rapidamente (Froud, Johal e Williams, 2002).

(9) O microcrédito caracteriza-se pela ampliação dos mecanismos de acesso a crédito para segmentos populacionais tradicionalmente excluídos desse mercado: trabalhadores autônomos informais, sem possibilidade de dar garantia individual, sem conta bancária, etc.

(10) Tradução nossa, do original: "By actively managing risk, the investing individual can adequately prepare for a future that is never secure and always rife with uncertainty. As a result, life itself becomes an asset to be managed".

(11) Nossas pesquisas em andamento, por exemplo, mostram que duas firmas concentram o mercado para os estudos de viabilidade econômico-financeira nas operações urbanas consorciadas nas Cidades de São Paulo, Rio de Janeiro, São Bernardo do Campo, Belo Horizonte e Curitiba.

(12) Os modelos de fluxo de caixa descontado são amplamente disseminados e usados no mundo das finanças corporativas. São elaborados a partir da projeção de uma renda líquida futura associada à utilização de um ativo ou propriedade durante determinado período. Esta projeção de renda futura é capitalizada (descontada) para o presente, utilizando a taxa de juros (que incorpora um prêmio de risco), para obter uma estimativa para o preço do ativo.

(13) Nesse sentido, a evolução da literatura crítica sobre a crise subprime representa um exemplo emblemático do potential de articular e territorializar as diversas vertentes críticas.

(14) Tradução nossa, do original: "Studies of urban redevelopment would indeed gain something with the financialization literature, so long as the former continue to attend not just to financial capital but also to the material and ideological mechanisms through which property is continually reproduced as a financial asset".

(15) Defendemos uma classificação como tema específico na literatura pela riqueza e diversidade dos estudos de caso. Isso abre uma possibilidade de articular os diversos estudos de caso com o debate sobre a variedade dos processos de reestruturação dos estados nacionais neoliberalização, etc. - (Barcellos de Souza, 2015).

(16) A capitalização significa trazer rendas e fluxos de caixa que ocorrerão no futuro para o presente. Antecipar e precificar essas rendas (calculando o chamado valor presente líquido) permite usar esses títulos como garantia para captar mais recursos.

(17) Tradução nossa, do original: "financial capital is dependent on the constant searching out, or the construction of, new asset streams, usually through a process of aggregation, which then - and only then - allows speculation to take place".

(18) Tradução nossa, do original: "The intricacies of infrastructure concessions suggest we need to broaden our lens to incorporate the local dimensions of financialisation. Most notably, given the extensive role of the local state in producing these markets, theorisations of financialisation at the local level must function as, or draw from, state theory".

(19) De acordo com as regras do TIF, a arrecadação tributária da área não é transferida para o fundo geral do município, mas é obrigatoriamente reinvestida no perímetro da área. Se a receita tributária efetivamente realizada não cobre o custo das intervenções da operação, os impostos gerais arrecadados pelo município complementam o déficit da operação do TIF, reduzindo, assim, os riscos para os investidores. 
(20) Tradução nossa, do original: "The local government became increasingly dependent on realising the yields from the project; the project programming became functional to the urgent need to unlock capital for realisation, rather than being a tool to respond to particular local needs. Local zoning regulations have not stopped the speculative management of the land by the different financial owners, but instead have allowed increases to the expected real estate output".

(21) Tradução nossa, do original: "[...] Financialization is a politically limited critique insofar as it is essentially a critique of what finance does, especially elsewhere -- of where its tentacles extend to, of the constituencies thus enrolled and ensnared, of the 'nonfinancial' logics thus adulterated -- and not of what finance is [...]."

(22) Informação disponível no site do Cade: http://sei.cade.gov.br/sei/institucional/pesquisa/ processo_exibir.php?tzuQpynCIZls_rHQcc3fMu8I2htJ1ahuckyi_C139hQjKmt586E2jVZ4mUCAE4 DWZjYqf4D-irFk5H6TRF6DKQ. Acesso em: 29 maio 2017.

\section{Referências}

AALBERS, M. B. (2008). The financialization of home and the mortgage market crisis. Competition and Change, v. 12, n. 2, pp. 148-166.

(org.) (2012). Subprime cities: the political economy of mortgage markets. Oxford, Wiley Blackwell.

(2015). The potential for financialization. Dialogues in Human Geography, v. 5, n. 2, pp. 214-219.

e CHRISTOPHERS, B. (2014). Centering Housing in Political Economy. Housing, Theory and Society, v. 31, pp. 1-21.

ARRETCHE, M. T. (1996). "Desarticulação do BNH e autonomização da política habitacional”. In: AFFONSO, R. de B. e SILVA, P. L. (orgs.). Descentralização e políticas sociais. São Paulo, Fundap.

ASHTON, P.; DOUSSARD, M. e WEBER, R. (2016). Reconstituting the state: city powers and exposures in Chicago's infrastructure leases. Urban Studies, v. 53, n. 7, pp. 1384-1400.

BARCELLOS DE SOUZA, M. (2012). Variedades de capitalismo e reescalonamento espacial do Estado no Brasil. Tese de Doutorado. Campinas, Universidade Estadual de Campinas.

(2015). Neoliberalização do Estado no Brasil: uma interpretação multiescalar. Revista eletrônica e-metropolis, n. 21, ano 6.

BERNDT, C. e BOECKLER, M. (2009). Geographies of circulation and exchange: construction of markets. Progress in Human Geography, v. 33, pp. 535-551.

BRAJATO, D. (2015). A efetividade dos instrumentos do Estatuto da Cidade: o caso da Aplicação do Parcelamento, Edificação ou Utilização Compulsórios no Município de Maringá (PR). Dissertação de Mestrado. Santo André, Universidade Federal do ABC.

BRENNER, N. et al. (2011). Cities for people, not for profit: critical urban theory and the right to the city. Abingdon/Nova York, Routledge. 
BRUNO, M. et al. (2011). Finance-Led Growth Regime no Brasil: estatuto teórico, evidências empíricas e consequências macroeconômicas. Revista de Economia Política, v. 31, n. 5, pp. 730-750.

CAGNIN, R. F. (2012). A evolução do financiamento habitacional no Brasil entre 2005 e 2011 e o desempenho dos novos instrumentos financeiros. Boletim de economia da Fundap, n. 11.

CALLON, M. (1998). "Introduction: the embeddedness of economic markets in economics". In: CALLON, M. (org.). The law of markets. Oxford, Blackwell.

CHARNOCK, G.; PURCELL, T. F. e RIBERA-FUMAZ, R. (2014). City of rents: the limits to the Barcelona model of urban competitiveness. International Journal of Urban and Regional Research, v. 38, n. 1, pp. 198-217.

CHRISTOPHERS, B. (2015). The limits to financialization. Dialogues in Human Geography, v. 5, n. 2, pp. 183-200.

COSTA, F. N. (2002). Bancarização, crédito popular e microcrédito. Disponível em: http://www.eco. unicamp.br/artigos/artigo274.htm. Acesso em: 4 dez 2016.

CYERT, R. e MARCH, J. G. (1963). A behavioral theory of the firm. Oxford, Wiley-Blackwell.

FAMA, E. F. (1970). Efficient capital markets: a review of theory and empirical work. Journal of Finance, v. 25 , pp. $383-417$.

FIELDS, D. (2014). Contesting the financialization of urban space: community organizations and the struggle to preserve affordable rental housing in New York City. Journal of Urban Affairs, v. 37, n. 2, pp. 144-165.

FIX, M. (2011). Financeirização e transformações recentes no circuito imobiliário no Brasil. Tese de Doutorado. Campinas, Universidade Estadual de Campinas.

FROUD, J.; JOHAL, S. e WILLIAMS, K. (2002). Financialization and the coupon pool. Capital \& Class, v. 78, pp. 119-151.

GUIRONNET, A. e HALBERT, L. (2015). Urban development projects, financial markets, and investors: $A$ Research Note. Chairville, École des Ponts Paritech.

GUIRONNET, A.; ATTUYER, K. e HALBERT, L. (2016). Building cities on financial assets: the financialization of property markets and its implications for city governments in the Paris city region. Urban Studies, v. 53, n. 7, pp. 1442-1464.

HALL, P. (1995). Cidades do amanhã. São Paulo, Perspectiva.

HARVEY, D. (1982). The limits to capital. Oxford, Blackwell.

HELLEINER, E. (1994). States and the re-emergence of global finance: from Bretton Woods to the 1990 s. Ithaca and London, Cornell University Press.

HENRIKSON, L. F. (2009). Are financial markets embedded in economics rather than society? A critical review of the performativity thesis. DIIS Working Paper. Copenhagen, Danish Institute for International Studies.

JESSOP, B. (2008). State Power. Cambridge, Polity Press.

KAIKA, M. e RUGIERRO, L. (2016). Land financialization as a "lived" process: the transformation of Milan's Bicocca by Pirelli. European Urban and Regional Studies, v. 23, n. 1, pp. 3-22. 
KLINK, J. J. (2013). Development regimes, scales and state spatial restructuring: change and continuity in the production of urban space in Metropolitan Rio de Janeiro, Brazil. International Journal of Urban and Regional Research, v. 37, n. 4, pp. 1168-1187.

KLINK, J. J. e DENALDI, R. (2014). On financialization and state spatial fixes in Brazil. A geographical and historical interpretation of the housing program My House My Life. Habitat International, v. 44, pp. 220-226.

(2015). On urban reform, rights and planning challenges in the Brazilian metropolis. Planning Theory, v. 15, n. 4, pp. 402-417.

KLINK, J. J. e STROHER, L. (2017). The making of urban financialization? An exploration of Brazilian urban partnership operations with building certificates. No prelo.

LEYSHON, A. e THRIFT, N. (2007). The capitalization of almost everything. The future of finance and capitalism. Theory, Culture \& Society, v. 24, n. 7-8, pp. 97-115.

LORRAIN, D. (2011). The discrete hand: global finance and the city. Revue française de science politique, v. 61, n. 6, pp. 1097-1122.

MACKENZIE, D. (2005). An engine, not a camera: how financial models shape markets. Cambridge, MIT Press, MA.

MALERONKA, C. (2010). Projeto e gestão na metrópole contemporânea. Um estudo sobre as potencialidades do instrumento "operação urbana consorciada" à luz da experiência paulistana. Tese de Doutorado. São Paulo, Universidade de São Paulo.

MARQUES, E. (org). (2016). Dossiê: Capitais do Urbano. Novos Estudos Cebrap, v. 35, n. 2, pp. 15-33.

MCALLISTER, P. (2017). The calculative turn in land value capture: Lessons from the English Planning System. Land Use Policy, v. 63, pp. 122-129.

MOREIRA, M. R. P. (2008). Distribuição de água na Região Metropolitana de São Paulo: tecnologias de universalização e produção do espaço. Dissertação de Mestrado. São Paulo, Universidade de São Paulo.

MUElleRleile, C. (2013). Turning Financial Markets inside Out: Polanyi, Performativity and Disembeddedness. Environment and Planning A, v. 45, n. 7, pp. 1625-1642.

OLIVEIRA, F. de (1988). O surgimento do antivalor. Capital, força de trabalho e fundo público. Novos Estudos Cebrap, v. 22, pp. 8-28.

PAULANI, L. M. (2011). “A inserção da economia brasileira no cenário mundial: uma reflexão sobre o papel do Estado e sobre a situação atual real à luz da história”. In: MÉXICO: LOGROS E RETOS DEL BRASIL CONTEMPORÂNEO. Anais. Cidade de México, UNAM, 24 a 26 de agosto.

PECK, J. (2012). Austerity urbanism. City: analysis of urban trends, culture, theory, policy, action, v. 16, n. 6, pp. 626-655.

(2013). Pushing austerity: state failure, municipal bankruptcy and the crises of fiscal federalism in the USA. Cambridge Journal of Regions, Economy and Society, v. 7, n. 1, pp. 17-44.

PECK, J. e WHITESIDE, H. (2016). Financializing Detroit. Economic Geography, v. 92, n. 3, pp. $235-268$.

PEREIRA, A. L. dos S. (2016). Intervenções em centros urbanos e conflitos distributivos: modelos regulatórios, circuitos de valorização, e estratégias discursivas. Tese de Doutorado. São Paulo, Universidade de São Paulo. 
ROBINSON, J. (2002). Global and world cities: a view off the map. International Journal of Urban and Regional Research, v. 26, n. 3, pp. 531-554.

ROCHA LIMA JÚNIOR, J. (2012). Começar de novo: Performance adiante das empresas de real estate de capital aberto no Brasil. In: XII CONFERÊNCIA INTERNACIONAL DA LARES - LATIN AMERICAN REAL ESTATE SOCIETY. Anais. São Paulo, 19 a 21 de setembro, pp. 1-21.

ROLNIK, K. (2013). Late neoliberalism: the financialization of homeownership and housing rights. International Journal of Urban and Regional Research, v. 37, n. 3, pp. 1058-1066.

(2015). Guerra dos lugares. A colonização da terra e da moradia na era das finanças. Tese de Livre Docência. São Paulo, Universidade de São Paulo.

ROLNIK, R. e KLINK, J. (2011). Crescimento econômico e desenvolvimento urbano. Por que nossas cidades continuam tão precárias? Novos Estudos Cebrap, v. 89, pp. 89-110.

ROLNIK, R. et al. (2014). Ferramentas para avaliação da inserção urbana dos empreendimentos do MCMV. Relatório de Pesquisa CNPQ. São Paulo, Universidade de São Paulo.

ROYER, L (2014). Financeirização da Política Habitacional: limites e perspectivas. São Paulo, Annablume.

RUTLAND, T. (2010). The financialization of Urban Redevelopment. Geography Compass, v. 4, n. 8, pp. 1167-1178.

SANDRONI, P. A. (2010). “New financial instrument of value capture in São Paulo: certificates of additional construction potential”. In: INGRAM, G. K. e HONG, Y. H. (orgs.). Municipal Revenues and Land Policies. Cambridge (Massachusetts), Lincoln Institute of Land Policy, pp. 218-237.

SANFELICI, D. e HALBERT, L. (2015). Financial markets, developers and the geographies of housing in Brazil: a supply side account. Urban Studies, jun. 19, pp. 1-21.

SAVINI, F. e AALBERS, M. (2015). The de-contextualisation of land use planning through financialisation: Urban redevelopment in Milan. European Urban and Regional Studies, pp. 1-17.

SHIMBO, L. (2012). Habitação Social de Mercado. A confluência entre Estado, empresas construtoras e capital financeiro. Belo Horizonte, C/Arte.

SOAITA, A. M. e SEARLE, B. A. (2016). Debt amnesia: homeowners' discourses on the financial costs and gains of homebuying. Environment and Planning A, v. 48, n. 6, pp. 1087-1106.

SWYNGEDOUW, E.; MOULAERT, F. e RODRIGUEZ, A. (2002). Neoliberalization in Europe: large scale urban development projects and the new urban policy. Antipode, v. 34, n. 3, pp. 542-577.

VAN DER ZWAN, N. (2014). Making sense of Financialization. Socio-Economic Review, v. 12, pp. 99-129.

WEBER, R. (2010). Selling city futures: the financialization of urban redevelopment policy. Economic Geography, v. 86, n. 3, pp. 251-274.

Texto recebido em 10/dez/2016

Texto aprovado em 17/mar/2017 